\title{
A Study on the Influence of Brand Extension Portfolio Strategy on Cannibalization in Low-cost Cosmetics Market
}

\author{
Man Seok Song \\ Department of Advertising and PR, Tong Myong University, Busan, Korea
}

Corresponding author: Man Seok Song, Department of Advertising and PR, Tong Myong University, 428 Sinseon-ro, Nam-gu, Busan 48520, Korea

Tel.: +82516292051

Fax: +82336292510

Email: consulting89@hanafos.com

Received January 06, 2020

Revised February 11, 2020

Accepted March 02, 2020

Published March 30, 2020

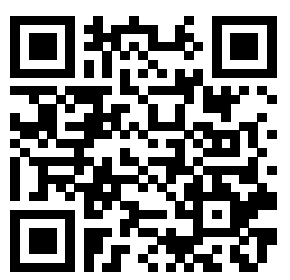

\section{Introduction}

국내 화장품 시장은 전반적인 국내 경기 침체 및 소비심리 위축 으로 브랜드 간 경쟁이 치열해지고 있으며, 화장품의 품질과 고객 만족에 대한 관심의 증대와 함께 감성중심의 소비 패턴 변화로 화 장품 산업의 경영환경이 고객중심으로 급격하게 이동하고 고객 지 향적 서비스 개념이 경영에 적극적으로 도입되는 가운데 경쟁적 환

\begin{abstract}
Purpose: This study is a cannibalization analysis of a family brand which is extended downward by a brand portfolio expansion strategy in the low-price cosmetics market. Brands such as THE FACE SHOP and BEYOND by LG Household \& Health Care, MISSHA and A'pieu by ABLE C \& C, and innisfree and ETUDE HOUSE by AMORE PACIFIC were set as the evaluation alternatives. The Bass diffusion model was applied to analyze the cannibalization, and cross analysis was conducted as an additional multiple analysis method. By performing positioning analysis, simultaneous research was performed on cannibalization analysis, market encroachment with competitive brands, and market competitiveness. Methods: Data collection was conducted from March 20 to April 21, 2018. We collected data from adult women who had used low-price cosmetics more than once, through a convenience sampling method. We received 287 answers from the total of 300 surveys and used these for the final analysis. Thirteen insincere or incomplete answers were excluded. The collected data were cross-analyzed by SPSS statistical package program to identify the purchasing conditions of low-price cosmetics and future brand conversion probability. A positioning map was prepared using biplot analysis. For demographical analysis, frequency analysis was also performed. Additionally, Bass diffusion model analysis was performed using sales time series data of each alternative evaluation brand. Results: Cannibalization was expected in all brands evaluated by Bass diffusion model analysis. The entry ratio was expected to increase, since the coefficient of imitation is higher in the propagation of new products than that of innovation. Conclusion: The results of the cannibalization analysis of brands in the low-cost cosmetics market have implications for various fields, such as measuring the performance of an expanded brand portfolio in an intensely competitive structure, launching new products, launching new brands in a new market, analyzing the market competition structure of competitive brands, and devising strategies to defend against cannibalization.
\end{abstract}

Keywords: Low-price cosmetics, Brand expansion, Cannibalization, Bass diffusion model, Positioning map 
브랜드 간 시너지 효과를 창출하고, 모브랜드를 중심으로 레버리지 (leverage)화 하여 새로운 수요를 창출하며 연관성을 유지하는 차 별화된 패밀리 브랜드 포트폴리오를 구축하고 있다.

Reddy et al. (1994)의 연구에 따르면 모기업의 브랜드 계열 확 장은 cannibalization이 발생함에도 불구하고 브랜드 계열 확장으 로 인한 판매 증가가 모기업에 도움이 될 수 있어 라인 확장 전략을 실행하는 충분한 이유가 된다고 하였다.

그러나 브랜드 확장을 잘못하여 적합한 브랜드 포트폴리오를 구 성하지 못하게 되면 기존 제품의 실패를 가져올 수도 있으며, 매출 액의 감소를 초래하는 등 흔히 말하는 "제살깎기" 즉, 자기시장잠식 (cannibalization, 이하 cannibalization으로 표기) 현상이 나타나 는 최악의 상황을 맞을 수 있으며(Loken \& John, 1993; John et al., 1998; Broniarczyk \& Alba, 1994), 시장효율이 저하되는 경 우가 발생할 수도 있다(Lomax et al., 1997). 그런가 하면 브랜드 확장을 계속할 경우 본래 브랜드가 갖는 이미지나 소비자에게 전 달하고자 하는 positioning 상의 위치가 달라지는 희석현상이 발생 하여 본래 브랜드에 치명적인 손실을 끼치게 될 수 있다(Loken \& John, 1993).

Cannibalization은 마케팅 실무자 및 학자에게는 친숙한 개념 이지만 측정에 관한 구체적인 방법론에 관한 연구는 거의 없으며 (Shin, 1997), 이를 측정하기 위한 합의된 개념과 표준화된 척도도 없다(Lomax et al., 1997). Sridhar Moorthy \& Png (1992) 역시 신제품을 대상으로 하는 연구에서 수리적인 모형을 이용하여 입증 하였으나 규범적인 조언만 하며 자기시장잠식을 어떻게 측정할 것 인가에 대해 언급은 하지 않았다.

화장품 산업계에서 브랜드 확장전략이 활발하게 전개되고 있 는 것과 달리 학술적인 접근은 상당히 부족하며, 최근에 들어와서 야 브랜드 확장의 성공에 영향을 미치는 요인들을 실증적으로 분 석하는 연구가 진행되고 있으나(Kwon \& Kim, 2013; Lee et al., 2016; Bae, 2015), 이에 대한 역효과는 상당한 중요한 문제임에도 불구하고 연구가 이루어지지 않고 있으며, 잘못된 브랜드 확장 포 트폴리오 전략에 따른 cannibalization에 대한 연구 또한 전무한 실 정이다.

최근 저가화장품 시장은 성숙기로 포화상태에 접어들고 있으 며 급속한 성장과 비례하여 브랜드 간의 치열한 경쟁이 이루어 지고 있다. 이미 이 시장에 자브랜드를 보유하고 있음에도 불구 하고 브랜드 확장전략으로 복수로 진출한 패밀리 브랜드로 인한 cannibalization이 발생하여 시장경쟁구조에 음(-)의 시너지 영향 을 미치지 않는가? 그리고 모브랜드 자산에 어떠한 영향을 미치는 가를 분석하기 위해 저가화장품 이용 소비자를 대상으로 실증 분석 하여 저가화장품 브랜드 확장 포트폴리오 정책 수립의 방향성을 위 한 기초정보를 제공하고자 한다.

본 연구에서는 저가화장품 시장에 대기업 계열의 화장품 브랜드 기업이 저가화장품 브랜드를 이미 복수의 포트폴리오를 구성하여
시장에 진출하고 있는 $\mathrm{LG}$ 생활건강의 더페이스샵과 비욘드, 에이블 씨엔씨의 미샤와 어퓨, 그리고 아모레퍼시픽그룹의 에뛰드하우스 와 이니스프리 등을 연구대상으로 설정하여 cannibalization에 대 한 연구를 진행하고자 한다.

접근방법으로는 Kim \& Shin (2008)과 Shin (1997) 등이 수행 한 cannibalization 분석을 위해 도입한 Bass (1969) 확산모형을 본 연구 목적에 맞게 도입하여 혁신계수(p)와 모방계수(q) 그리고 포화잠재 시장규모 $(\mathrm{m})$ 를 파악하고 Bass (1969) 확산모형이 제공하 지 못하는 것을 보완하는 복수의 분석방법으로 시장경제적 측면에 서 직접 소비자를 대상으로 설문조사를 실시하기로 한다.

이는 Jamieson \& Bass (1989)가 제안한 cannibalization을 측 정하는 또 다른 방법인 소비자를 대상으로 하는 시장조사 결과를 이용하여 이탈률과 구매의도를 파악하여 각 평가 브랜드의 충성도 와 이탈률 그리고 신규고객유입률을 평가하고자 하며, byplot 분석 을 동시에 수행하여 각 평가대안 브랜드의 유사성과 선택속성의 차 별화를 측정하는 Figure 1과 같은 positioning map으로 나타내는 cannibalization 분석도 실시한다.

이러한 분석 결과는 화장품이 질적 차이가 뚜렷하게 인식이 되지 않는 특징을 갖고 있어(Lee, 2016), 포트폴리오 확장전략으로 하향 확장된 저가화장품 패밀리 브랜드 간 지나친 경쟁으로 인한 마케팅 비용의 과도한 지출과 함께 매출액은 높은 성장률을 보이지만 영업 이익은 오히려 감소하고 있는 경영환경에서 수익구조 개선을 위한 브랜드 포트폴리오 확장전략을 수립하는 데 중점을 두어야 할 자료 로 활용하고자 한다.

\section{Methods}

\section{1. 연구대상 및 자료수집}

본 연구 설문조사 대상의 표집은 2018년 9월 20일부터 10월 21 까지 부산지역에 거주하고 있는 저가화장품 이용한 경험이 있는 성 인 여성을 대상으로 하였으며, 실증분석을 위해 총 300 부의 설문지 를 배부하였으며 그 중 측정 주요 변수의 응답 누락과 복수 응답으 로 인해 본 연구를 위한 분석을 실시하기에 불성실한 응답자를 제 외한 총 287 부의 설문지를 사용하여 본 연구를 위한 실증 분석을 실시하였다.

그리고 또 다른 cannibalization의 측정을 위한 방법으로 Bass (1969) 확산모형 분석을 위해 연구 대상 저가화장품 브랜드의 매출 액 시계열 자료를 이용하였다.

\section{2. 측정항목 및 내용}

본 연구는 설문지법과 연구대상 저가화장품 브랜드의 매출액 시 계열 자료를 이용하였으며, 설문 문항은 크게 연구대상의 인구통계 적 특성과 cannibalization의 측정을 위한 biplot 분석 측정 항목과 
충성도와 이탈률 그리고 신규고객유입률 등의 분석을 위해 총 155 문항의 측정항목으로 구성되어져 있으며, 본 설문조사를 위해 5 점 리커트 척도와 인구통계적 특성 측정을 위한 명목척도와 서열척도 그리고 빈도분석 측정항목이 사용되었으며, 구체적인 내용의 분석 결과는 Table 1 , Table 2, Table 3, Table 4, Table 5, Table 6, 그 리고 Figure 1 과 같다.

\section{3. 분석방법}

Cannibalization 분석을 위한 Bass (1969) 확산모형 적용을 위해서는 평가대상 각 저가화장품 브랜드 매출의 시계열 자료를 Equation 1에 적용하여 계산하였으며, Table 2 와 같은 결과를 도 출하였다. SPSS사의 통계패키지 프로그램 22.0 버전을 사용하여 평가대상 저가화장품 브랜드 현재 사용 실태 및 향후 브랜드 구매 의도를 파악하기 위하여 교차분석을 실시하여 Table 5 와 Table 6 과 같은 충성도, 단기미래시장점유율과 신규고객유입률 등을 도출하 였다.

그리고 Bass (1969) 확산모형을 보완하기 위한 cannibalization 분석의 시각화를 위해 16 개의 평가속성을 적용한 biplot 분석을 실 시하여 Figure 1과 같이 positioning map을 작성하였으며 인구통 계적 분석을 위해서 빈도 분석을 실시하여 Table 1 과 같은 결과를 도출하였다.

이러한 평가대상 저가화장품의 브랜드 확장전략으로 인한 cannibalization의 가능성을 분석하기 위한 평가과정을 더 구체적 으로 살펴보면 먼저 1단계 방법으로 모브랜드의 시장확대와 경쟁 우위를 위하여 브랜드 하향확장 전략으로 복수의 포트폴리오를 구 성한 저가화장품 패밀리 브랜드에 대해 Bass (1969) 확산모형 분석 을 적용하여 cannibalization 현상의 메커니즘을 평가하였으며, 2 단계 방법으로 평가대안에 대한 평가요소별 byplot 분석을 실시하 여 positioning map을 작성하고 도출된 각 평가대안과 평가요소의 유클리디언 거리(eucledian distance)의 근접성으로 유사도를 측정 할 수 있어 cannibalization 현상 검증을 시각화할 수 있으며, 또한 각 저가화장품 브랜드의 시장점유율과 같은 mind share를 구할 수 있다. 3 단계 방법으로 소비자를 대상으로 설문 측정 방법으로 평가 브랜드에 대한 교차분석을 통하여 충성도, 이탈률, 신규고객유입 률, 그리고 단기미래시장점유율 등을 제시하여 브랜드 포트폴리오 확장을 하고자 하는 경영진의 의사결정 효율성과 의사결정 질을 높 이는 과학적 접근방법을 제시할 수 있다.

\section{4. cannibalization의 측정을 위한 방법론의 고찰}

산업현장의 마케터들은 전통적으로 cannibalization을 신 제품 출시로 인한 기존제품 판매 감소 효과를 일으키는 Sales cannibalization이라고 인식하며, 신제품개발에 나쁜 영향을 미 치는 것으로 인식하고 있으며(Mason \& Milne, 1994). Copulsky (1976)는 같은 회사에 의해서 제공되는 두 가지 상품 중 상품 1 의
고객이 상품 2 의 고객으로 전환되며, 새로운 상품의 등장으로 인해 기존에 존재하던 기존 상품의 시장점유율에 비례하여 발생하는 경 향이 있다 하였다.

기존 제품의 잠재고객 중 일부는 신제품과 기존제품 간의 비교 선택에서 신제품을 선택하거나 선택을 보류하여 신제품의 잠재고 객으로 빠져나감으로써 기존 제품의 성장세가 감소되며, 또는 신제 품의 확산으로 인하여 부정적인 구전효과가 기존 제품에 미치게 됨 에 따라 구매확률이 감소함으로써 기존 제품의 성장세는 둔화되기 도 한다. 즉 cannibalization은 잠재구매자의 크기의 감소와 음의 구전효과로 인한 선택확률의 감소로 인한 영향으로 볼 수 있다.

본 연구를 위한 확장된 저가화장품 브랜드의 cannibalization 분 석을 위해 Bass (1969) 확산모형을 도입하여 분석을 하고자 한다. Bass (1969)의 확산모형 분석은 시계열 자료를 이용하여 Equation 1 과 같은 필요 수식과 함께 시장을 정의하는 방법으로 확산 과정의 기본 매커니즘을 추출하여 확산이론의 토대를 구축하는 공헌을 하 고 있으며, 현재 많은 연구자가 다양한 분야에서 그들의 연구를 위 해 Bass (1969) 확산모형을 도입하여 사용하고 있다(Shin, 1997; Kim \& Shin, 2008; Peres et al, , 2010).

Equation 1:

$$
\begin{aligned}
& (\mathrm{f}(\mathrm{t})) /(1-\mathrm{F}(\mathrm{t}))=\mathrm{p}+\mathrm{qF}(\mathrm{t})=\mathrm{p}+\mathrm{q}(\mathrm{Y}(\mathrm{t}) / \mathrm{m}) \\
& \mathrm{f}(\mathrm{t})=\mathrm{t} \text { 시점의 구매확률 } \\
& \mathrm{F}(\mathrm{t})=\mathrm{t} \text { 시점의 누적구매확률 } \\
& \mathrm{Y}(\mathrm{t})=\mathrm{t} \text { 시점의 누적가입자 수 } \\
& \mathrm{m}=\text { 궁극적인 채택자의 수 } \\
& \mathrm{p}=\text { 혁신계수(enovation coefficient) } \\
& \mathrm{q}=\text { 모방계수(imitation coefficient) }
\end{aligned}
$$

본 연구의 효율적인 cannibalization 분석을 위해 Bass (1969) 확산모형 분석을 통해 확장된 패밀리 브랜드 간의 cannibalization 현상을 밝혀낸 다음 Bass (1969) 확산모형이 제공하지 못하는 평 가대안 속성의 차별화 정도를 파악하고 브랜드 간의 유사도를 positioning map을 통해서 비교하고 보완하여 확인하기 위한 방법 으로 도입하고자 한다.

이 방법에 의하면 시장 구조와 신규 제품의 positioning과 전략 을 결정하는 데 있어서 도움(Fraser \& Bradford, 1985; Urban et al., 1984)이 될 뿐만 아니라 저가화장품 브랜드의 상대적인 위치 까지 확인할 수 있으므로 경영자에게 매우 유용한 정보를 제공할 수 있다고 하겠다. positioning map 분석을 위해 Song (2018)과 Song \& Seol (2016) 등이 그들의 연구논문에 적용한 byplot 기법 을 이용하여 Figure 1과 같은 positioning map을 얻을 수 있으며, Table 3 과 Table 4에서와 같이 mind share를 알 수 있으며, 평가대 안과 평가요소의 정위화된 좌표값을 알 수 있어 이들의 eucledian distance의 차별화되지 못한 유사성으로 cannibalization 현상을 규명할 수 있다.

그리고 본 연구인 저가화장품 시장에서의 브랜드 확장 포트폴리 
오 전략이 cannibalization에 미치는 영향 연구를 위한 Bass (1969) 확산모형의 보완하기 위해 또 다른 복수의 방법으로 교차분석을 실 시하여 저가화장품 이용 소비자로부터 정의된 평가대상 저가화장품 브랜드의 충성도, 이탈률, 신규고객유입률, 그리고 단기미래시장점 유율 등의 분석 결과인 Table 5 와 Table 6 을 얻을 수 있다.

\section{Results and Discussion}

\section{1. 일반적 특성}

본 연구 설문에 응답한 표본의 인구통계적 특성을 살펴보면 Table 1과 같다. 모두 저가화장품 이용한 경험이 있는 성인 여성 을 대상으로 설문 조사하였으며, 전체 표본 287 명 중 연령별 분포 는 20 대가 109 명 $(39.2 \%$ )으로 가장 높게 나타났으며, 50 대 이상 의 경우 16 명 $(5.7 \%)$ 으로 가장 낮은 것으로 나타났다. 월평균 화장 품 구매 비용은 10,000 원 이상에서 30,000 원의 구간에서는 102
명(36.7\%)으로 나타났으며, 월평균 100,000 원 이상에서 150,000 원 사이 구간은 19 명(6.8\%)으로 가장 낮게 나타났다. 그리고 가구 당 월평균 소득은 300 만 원 아래가 169 명(60.8\%)으로 나타났으며, 600 만 원 이상의 소득자는 13 명(4.7\%)으로 파악되어져 나타났다.

\section{Bass 확산모형 분석을 이용한 cannibalization 실증 분석 결과}

Bass (1969) 확산모형 분석은 혁신계수(p), 모방계수(q), 포화잠 재 시장규모 $(\mathrm{m})$ 의 값을 알 수 있다는데 장점이 있다. 포화잠재 시 장규모 $(\mathrm{m})$ 는 전체 시장규모의 예상 수이고 혁신계수(p), 모방계수 (q)는 보통 0 에서 1 의 값을 가지는 변수로서 연구대상의 혁신계수 (p), 모방계수(q)의 추정은 연구대상 화장품 브랜드 기업의 매출 시 계열 자료를 $\operatorname{Bass}(1969)$ 확산모형을 이용하여 추정하였다.

연구분석 결과에 대한 설명력을 나타내는 $\mathrm{R}^{2}$ 값은 적합도를 나타 내는 것으로 $\mathrm{R}^{2}$ 값이 1 에 가까우면 적합도가 높은 것으로 설명력이 높은 것이고 0 에 가까우면 적합도가 낮으며 설명력 또한 낮다는 것 을 나타낸다. Table 2 에 나타난 것과 같이 $\mathrm{R}^{2}$ 값이 전부 0.9 이상으

\section{Table 1. Subject characteristics}

\begin{tabular}{|c|c|c|c|}
\hline category & & Frequency $(\mathrm{N})$ & Percentage (\%) \\
\hline \multirow{5}{*}{ Age } & Below 20 & 38 & 13.7 \\
\hline & $21-30$ & 109 & 39.2 \\
\hline & $31-40$ & 69 & 24.8 \\
\hline & $41-50$ & 46 & 16.6 \\
\hline & Over 51 & 16 & 5.7 \\
\hline \multirow{6}{*}{$\begin{array}{l}\text { Monthly cosmetics } \\
\text { purchase amount }\end{array}$} & Below 10,000 won & 33 & 11.9 \\
\hline & 10,001 won-30,000 won & 102 & 36.7 \\
\hline & 30,001 won- 50,000 won & 59 & 21.2 \\
\hline & 50,001 won- 100,000 won & 41 & 15.1 \\
\hline & 100,001 won- 150,000 won & 19 & 6.8 \\
\hline & Over 150,001 won & 23 & 8.3 \\
\hline \multirow{5}{*}{ Monthly Income } & Below 3 million won & 113 & 40.7 \\
\hline & $3,000,001$ won- $4,000,000$ won & 56 & 20.1 \\
\hline & $4,000,001$ won-5,000,000 won & 54 & 19.4 \\
\hline & $5,000,001$ won- $6,000,000$ won & 42 & 15.1 \\
\hline & Over $6,000,000$ won & 13 & 4.7 \\
\hline Total & & 287 & 100 \\
\hline
\end{tabular}

Table 2. Results of Bass diffusion model analysis

\begin{tabular}{|c|c|c|c|c|c|}
\hline Low cost cosmetic brands of & uation alternatives & $p$ & $q$ & $\mathrm{~m}$ & $\mathrm{R}^{2}$ \\
\hline \multirow{2}{*}{ LG Household \& Health Care } & The FACE SHOP & 0.00622 & 0.23726 & 99663.08749 & 0.95526 \\
\hline & BEYOND & 0.00119 & 0.53635 & 30726.18340 & 0.99436 \\
\hline \multirow{2}{*}{ Able C\&C cosmetic } & MISSHA & 0.00197 & 0.32420 & 54683.26786 & 0.92871 \\
\hline & A'pieu & 0.00986 & 0.36316 & 6662.55164 & 0.99502 \\
\hline \multirow{2}{*}{ Amore Pacific cosmetic } & innisfree & 0.00739 & 0.27476 & 96933.03129 & 0.94146 \\
\hline & ETUDE HOUSE & 0.00304 & 0.30595 & 39794.68864 & 0.94943 \\
\hline
\end{tabular}




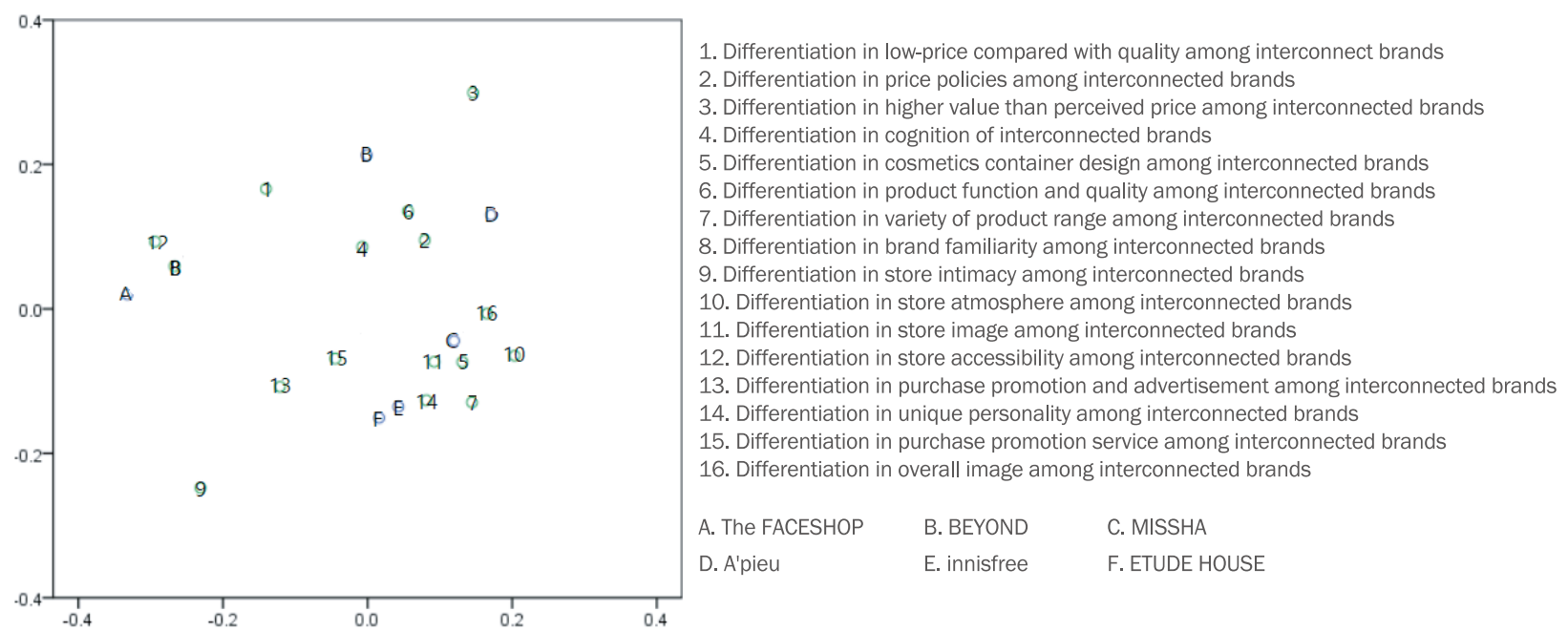

Figure 1. Positioning map

In the positioning map analysis result, cannibalization is expected between Etude House and innisfree. Focusing on the two downwardly extended brands, evaluation factors $14,7,15,11$, and 5 are in close positions. Due to the similarity of these evaluation factors, the cannibalization phenomenon is expected and differentiation between evaluation factors is required. Refer to Tables 3 and 4 for coordinate values of each evaluation attribute in the positioning map.

로 나타나 본 연구 수행을 위한 Bass (1969) 확산모형은 모두 적합 하며 설명력이 높다하겠다.

Bass (1969) 확산모형의 추정결과는 Table 2와 같다. LG생활 건강 화장품의 더페이스샵의 혁신계수(p)는 0.00622 , 모방계수(q) 는 0.23726, 포화잠재 시장규모 $(\mathrm{m})$ 는 99663.08749 , 설명변수 $\left(\mathrm{R}^{2}\right)$ 는 0.95526으로 모형이 적합하게 도출되었으며, 비욘드의 경우 혁 신계수(p)는 0.00119, 모방계수(q)는 0.53635, 포화잠재 시장규모 $(\mathrm{m})$ 는 30726.18340 , 그리고 설명변수 $\left(\mathrm{R}^{2}\right)$ 는 0.99436 으로 모형이 적합하게 도출되었다.

에이블씨엔씨 화장품의 미샤의 혁신계수(p)는 0.00197, 모방계 수(q)는 0.32420 , 포화잠재 시장규모 $(\mathrm{m})$ 는 54683.26786, 설명변 수 $\left(\mathrm{R}^{2}\right)$ 는 0.92871 로 모형이 적합하게 도출되었으며, 어퓨의 경우 혁신계수(p)는 0.00986, 모방계수(q)는 0.36316, 포화잠재 시장규 모 $(\mathrm{m})$ 는 6662.55164 , 그리고 설명변수( $\left.\mathrm{R}^{2}\right)$ 는 0.99502 로 모형이 적합하게 도출되었다.

아모레퍼시픽그룹의 에뛰드하우스는 혁신계수(p)가 0.00304, 모방계수(q)는 0.30595, 포화잠재 시장규모(m)는 39794.68864, 설명변수 $\left(\mathrm{R}^{2}\right)$ 는 0.94943 으로 모형이 적합하게 도출되었으며, 이니 스프리의 경우 혁신계수(p)는 0.00739, 모방계수(q)는 0.27476, 포화잠재 시장규모 $(\mathrm{m})$ 는 96933.03129, 그리고 설명변수(R2)는 0.94146 으로 모형이 적합하게 도출되었다.

본 연구에서의 분석 결과를 살펴보면 혁신계수(p)의 경우에는 Sultan et al. (1990)의 연구 결과에서 도출된 평균값보다 낮게 나 타났으나 모방계수(q)가 제시된 평균값보다 높게 나타나는 결과를 보이고 있어 이는 상대적으로 진입장벽이 낮은 화장품 산업계의 특 수성을 고려하여야 할 것이다. 그리고 이들의 연구 결과와 같이 모 방계수(q)가 혁신계수(p)보다 높은 것으로 나타나 상대적으로 진입 비율이 증가한다고 볼 수 있으며, 신제품의 확산과 수용에 있어서 도 중요한 의미를 갖는다. 평가대상 브랜드와 확장된 브랜드 간의 시장잠식 그리고 확장된 패밀리 브랜드 간의 cannibalization 가능 성이 발생할 수 있다.

Table 2에서 이니스프리의 경우 에뛰드하우스보다 혁신계수(p) 가 2.43 배 높은 것으로 나타났으며, 모방계수(q)의 경우는 에뛰드 하우스가 1.11 배 높은 것으로 나타났다. 이러한 결과는 이니스프리 는 제품 출시 당시에 높은 판매율의 성장을 보일 것이나 그 이후로 는 계속 낮아질 수밖에 없다. 그리고 에뛰드하우스는 혁신계수 가 치가 이니스프리보다 낮게 나타나 제품의 판매율 상승 기대는 지연 될 것이며, 포화잠재 시장규모 $(\mathrm{m})$ 가 현재 시장규모보다 작게 되면 신규채택자의 수도 감소되기 시작하는 시장잠식 효과가 예상된다.

일반적으로 혁신계수는 모방계수에 비교해 확산에 큰 영향을 미 치지는 못하는 것으로 알려져 있으며, 확산과정에서 모방계수에 의 하여 확산이 주도되는 특징이 있으며(Talukdar et al., 2002), 모방 계수의 값이 클수록 확산은 빠르게 일어난다(Lee et al., 2015). 그 리고 본 연구결과에서도 동일하게 적용되는 것으로 나타났다.

\section{Positioning map을 이용한 cannibalization 분석 결과}

평가대안 저가화장품 positioning map 분석 결과는 Figure 1 과 같이 얻을 수 있게 되며, Figure 1에 도출된 바와 같이 평가속 성에 대한 좌표를 보면 이니스프리의 경우 '상호연상되는 브랜드 간 독특한 개성의 차별화', '상호연상되는 브랜드 간 구색의 다양함 의 차별화', '상호연상되는 브랜드 간 구매촉진 서비스의 차별화' 그 리고 '상호연상되는 브랜드 간 점포 이미지의 차별화' 등이 강하게 
positioning 되어져 있으며, 더페이스샵의 경우 '상호연상되는 브랜 드 간 친숙성의 차별화'와 '상호연상되는 브랜드 간 점포 접근성의 차별화'로 positioning되어져 있고 미샤의 경우 '상호연상되는 브랜 드 간 점포 이미지의 차별화', '상호연상되는 브랜드 간 화장품 용 기 디자인의 차별화', '상호연상되는 브랜드 간 전반적인 이미지의 차별화', '상호연상되는 브랜드 간 점포 분위기의 차별화'가 강하게 positioning되어져 있음을 알 수 있다.

Table 3은 Figure 1인 positioning map에서의 평가대안 좌표값 으로 각 평가대안의 X축과 $\mathrm{Y}$ 축에 대한 좌표값을 나타내고 있으며 mind share는 소비자의 심상에 나타내고 있는 점유율로서 현재의 시장점유율 선행지표로 대체 가능하다. 현재 mind share에서 가장 높게 나타난 것은 이니스프리(0.183)로 나타났으며, 에이블씨엔씨 의 미샤(0.156)와 어퓨(0.156)가 평가대안 브랜드 중 가장 낮은 점 유율과 포지션을 나타내고 있는 것으로 도출되어져 있다.

아모레퍼시픽그룹의 하향확장된 패밀리 브랜드 이니스프리와 에
뛰드하우스의 경우 두 브랜드간의 eucledian distance가 근접하게 붙어 있는 것으로 나타났으며, 두 브랜드를 중심으로 '상호연상되는 브랜드 간의 고유한 개성의 차별화', '상호연상되는 브랜드 간 구색 의 다양함의 차별화', '상호연상되는 브랜드 간 구매촉진 서비스의 차별화', '상호연상되는 브랜드 간 점포 이미지의 차별화' 그리고 '상 호연상되는 브랜드 간 용기 디자인의 차별화' 등이 가까이 포지션하 고 있어 이들 평가요소의 유사성으로 cannibalization 현상이 예상 되어지고 있음을 알 수 있어 평가요소간의 차별화가 요구되어진다.

그리고 LG생활건강의 더페이스샵과 비욘드 브랜드의 경우는 포 지셔닝 맵상에서 브랜드간의 eucledian distance가 상대적으로 멀 리 나타나 다른 평가대안 브랜드 보다 유사성이 상대적으로 낮게 도출되어졌다.

\section{4. 저가화장품 브랜드 전환행렬 분석 결과}

모브랜드의 브랜드 확장 포트폴리오 전략으로 저가화장품 시장

\section{Table 3. Evaluation of alternative value on the positioning map}

\begin{tabular}{|c|c|c|c|c|}
\hline \multirow{2}{*}{\multicolumn{2}{|c|}{ Evaluation of alternative low cost cosmetics brand }} & \multicolumn{3}{|c|}{ Coordinate value of positioning map } \\
\hline & & Mind share & $\mathrm{X}$ axis & Y axis \\
\hline \multirow{2}{*}{ LG Household \& Health Care } & The FACE SHOP & 0.167 & -0.332 & 0.020 \\
\hline & BEYOND & 0.162 & -0.001 & 0.213 \\
\hline \multirow{2}{*}{ Able C\&C cosmetic } & MISSHA & 0.156 & 0.120 & -0.044 \\
\hline & A'pieu & 0.156 & 0.171 & 0.130 \\
\hline \multirow{2}{*}{ Amore Pacific cosmetic } & innisfree & 0.183 & 0.043 & -0.135 \\
\hline & ETUDE HOUSE & 0.176 & 0.016 & -0.151 \\
\hline Total & & 1.000 & & \\
\hline
\end{tabular}

\section{Table 4. Evaluation element attribute value in positioning map}

\begin{tabular}{|c|c|c|}
\hline \multirow{2}{*}{ Evaluation element } & \multicolumn{2}{|c|}{ Coordinate value of positioning map } \\
\hline & $\mathrm{X}$ axis & Y axis \\
\hline 1. Differentiation in low-price compared with quality among interconnect brands & -0.141 & 0.166 \\
\hline 2. Differentiation in price policies among interconnected brands & -0.079 & 0.095 \\
\hline 3. Differentiation in higher value than perceived price among interconnected brands & 0.146 & 0.299 \\
\hline 4. Differentiation in cognition of interconnected brands & -0.007 & 0.086 \\
\hline 5. Differentiation in cosmetics container design among interconnected brands & 0.131 & -0.074 \\
\hline 6. Differentiation in product function and quality among interconnected brands & 0.056 & 0.135 \\
\hline 7. Differentiation in variety of product range among interconnected brands & 0.144 & -0.129 \\
\hline 8. Differentiation in brand familiarity among interconnected brands & -0.267 & 0.059 \\
\hline 9. Differentiation in store intimacy among interconnected brands & -0.231 & -0.248 \\
\hline 10. Differentiation in store atmosphere among interconnected brands & 0.203 & -0.065 \\
\hline 11. Differentiation in store image among interconnected brands & 0.092 & -0.073 \\
\hline 12. Differentiation in store accessibility among interconnected brands & -0.294 & 0.093 \\
\hline 13. Differentiation in purchase promotion and advertisement among interconnected brands & -0.121 & -0.108 \\
\hline 14. Differentiation in unique personality among interconnected brands & 0.081 & -0.127 \\
\hline 15. Differentiation in purchase promotion service among interconnected brands & -0.045 & -0.069 \\
\hline 16. Differentiation in overall image among interconnected brands & 0.165 & -0.006 \\
\hline
\end{tabular}


에서 하향확장된 패밀리 브랜드의 cannibalization을 분석하기 위 해 선행연구로부터 분석방법을 도입 실시한 Bass (1969) 확산모형 의 제한성을 보완하기 위한 연구 방법으로 도입한 positioning map 분석과 교차분석을 이용한 브랜드 전환행렬 분석은 저가화장품 이 용 소비자를 대상으로 직접 측정한 설문 결과를 이용하여 각 평가 대안 브랜드의 충성도와 이탈고객률과 신규고객유입률 그리고 다 른 평가대안 브랜드로부터의 유입고객을 파악하여 cannibalization 과 경쟁 관계에 있는 저가화장품 패밀리 브랜드로부터의 시장잠식
도 파악하고자 하였다.

이러한 분석결과는 Table 2 의 cannibalization 측정을 위한 각 브랜드 별 Bass (1969) 확산모형 추정 결과의 해석과 positioning map 분석 결과인 Table 3 과 Table 4 의 분석 결과와 유사한 결과로 나타났다. Table 5 와 Table 6 에서 현재시장점유율이 가장 높게 나 타난 브랜드는 이니스프리가 $30.7 \%$ 로 나타났으며, 가장 낮은 현재 시장점유율을 나타내고 있는 브랜드는 미샤와 어퓨로 각각 $6.3 \%$ 의 현재시장점유율을 나타내고 있는 것으로 나타났다. 이는 Table 3 의

Tables 5. Cross analysis of currently used cosmetics brands and intended-future-use cosmetics brands

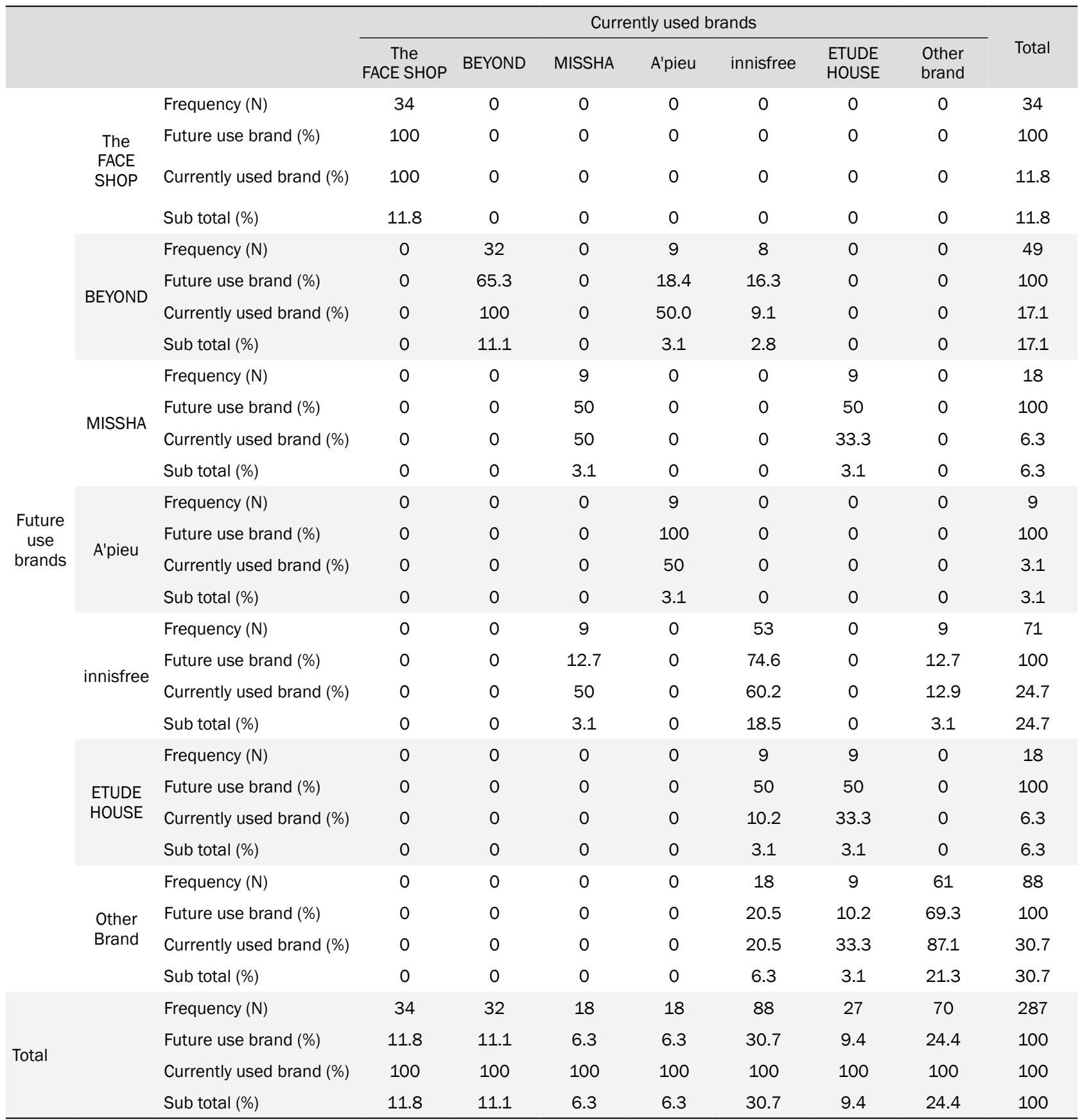


분석 결과에서 이 두 브랜드의 mind share 분석 결과 각각 $15.6 \%$ 의 포지션으로 가장 낮게 도출된 것과 동일한 분석 반응을 보이고 있다.

그리고 Table 5에서 이 두 브랜드의 향후 구매선택확률인 신규고 객유입률은 미샤의 경우 전체 연구 대상자 중 $3.1 \%$ 가 선택의도를 밝혔으며, 이들은 모두 에뛰드하우스 브랜드 이용자인 것으로 나타 났다. 어퓨의 경우 신규고객유입은 없으나 다른 브랜드인 비욘드로 전환하겠다는 이탈고객이 $50 \%$ 로 나타났다.

Table 5 에서 가장 높은 충성도를 보이고 있는 것은 LG생활건강 의 더페이스샵 $(100 \%)$ 과 비욘드 $(100 \%)$ 의 패밀리 브랜드로 나타났 으며, 가장 낮은 충성도를 보이고 있는 것은 에이블씨엔씨 화장품 의 미샤 $(50 \%)$ 와 어퓨 $(50 \%)$ 로 나타났다. 어퓨의 경우는 신규고객유 입이 없이 $50 \%$ 의 고객이 비욘드로 전환하는 것으로 나타나 단기미 래시장점유율은 가장 낮은 $3.1 \%$ 를 유지하는 것으로 나타났다. 미 샤의 경우는 이니스프리로 $50 \%$ 의 이탈고객이 발생하였으나 에뛰 드하우스로부터 $50 \%$ 의 신규고객유입이 발생하여 단기미래시장점 유율은 동일한 것으로 나타났다.

신규고객유입률이 가장 높게 나타난 것은 비욘드 화장품(34.7\%) 으로 나타났으며, 가장 낮은 신규고객유입률로 나타난 브랜드는 더 페이스샵과 어퓨로 각각 $0 \%$ 의 신규고객유입률을 나타내고 있다.

Table 5 로부터 cannibalization 현상이 예측되는 전체 브랜드의 이탈고객과 신규고객유입률을 살펴보면 전체 $100 \%$ 에서 충성고객 률을 빼면 브랜드별 이탈고객률을 알 수 있는데, 더페이스샵 이탈 고객률 $=100 \%-100 \%=0 \%$, 비욘드 이탈고객률 $=100 \%-100 \%=0 \%$, 미샤 이탈고객률 $=100 \%-50 \%=50 \%$, 어퓨 이탈고객률 $=100 \%-$ $50 \%=50 \%$, 이니스프리 이탈고객률 $=100 \%-60.2 \%=39.8 \%$ 이며, 에 뛰드하우스 이탈고객률 $=100 \%-33.3 \%=66.7 \%$ 이다. 이탈고객률은 에뛰드하우스가 가장 높은 것으로 나타났다.

신규고객유입률은 단기미래시장점유율 전체 $100 \%$ 에서 향후 구 매의도 화장품 브랜드 중 \%를 빼면 되는데 이들의 신규고객유입률 은 다음과 같다. 더페이스샵 신규고객유입률 $=100 \%-100 \%=0 \%$ 이며, 비욘드 신규고객유입률 $=100 \%-65.3 \%=34.7 \%$, 미샤 신규
고객유입률 $=100 \%-50 \%=50 \%$ 로 나타났다. 어퓨 신규고객유입률 $=100 \%-100 \%=0 \%$ 로 나타났으며, 이니스프리 신규고객유입률 $=100 \%-74.6 \%=25.4 \%$ 로 나타났고, 에뛰드하우스 신규고객유입률 $=100 \%-50.0 \%=50.0 \%$ 로 나타났다.

더페이스샵의 경우는 이탈고객률도 $0 \%$ 이며, 신규고객유입률 도 $0 \%$ 로 나타났으며, 가장 높은 이탈고객률을 나타내고 있는 브 랜드는 에뛰드하우스 $(66.7 \%)$ 이며, 그 다음이 미샤와 어퓨로 각각 $50 \%$ 의 분포를 나타내고 있는 것으로 나타났다. 그리고 이니스프리 (39.8\%)의 순서로 나타났다. 어퓨의 경우 이탈고객율이 $50 \%$ 로 나 타났으며, 신규고객유입률은 더페이스샵과 더불어 $0 \%$ 로 나타나 미 래시장점유율이 가장 낮게 나타났다. 이와 같은 Table 5 의 분석결 과는 Table 6 과 같이 요약할 수 있다.

가장 높은 이탈고객률을 나타내고 있는 브랜드인 에뛰드하우스 (66.7\%)의 경우 이니스프리(39.8\%)보다 이탈고객률이 $26.9 \%$ 높고 신규고객유입률은 $24.6 \%$ 높은 것으로 나타났으며, 충성도는 이니 스프리보다 $26.9 \%$ 낮은 것으로 나타났다. 이러한 결과는 어떤 기 회가 주어진다면 언제든지 다른 화장품 브랜드로 전환 가능성이 있 음을 시사한다.

에뛰드하우스의 경우 현재 이용고객의 수는 9 명이나 향후 에뛰 드하우스 브랜드를 구매 선택할 고객의 수가 9 명으로 나타났다. 이 유입고객은 같은 모브랜드인 아모레퍼시픽그룹의 패밀리 브랜드 인 이니스프리의 고객으로부터 유입되는 고객으로서 이니스프리의 cannibalization 현상이 발생하는 것으로 해석된다. 이러한 결과는 Figure 1의 positioning map 분석의 결과와도 무관하지 않다.

\section{Conclusion}

본 연구는 저가화장품 시장에서 브랜드 포트폴리오 확장전략으 로 하향확장된 패밀리 브랜드에 대한 cannibalization 분석으로 Bass (1969) 확산모형을 적용하여 cannibalization을 분석하였으 며, 또 다른 복수의 분석방법으로는 positioning map 분석과 교차

Table 6. Market characteristics of evaluation alternative low-cost cosmetics brands

\begin{tabular}{|c|c|c|c|c|c|c|}
\hline Brand name & & $\begin{array}{l}\text { Current market } \\
\text { share }(\%)\end{array}$ & $\begin{array}{c}\text { Future market } \\
\text { share (\%) }\end{array}$ & $\begin{array}{c}\text { Loyal } \\
\text { customer (\%) }\end{array}$ & $\begin{array}{c}\text { Leaving } \\
\text { customer (\%) }\end{array}$ & $\begin{array}{c}\text { New } \\
\text { customer (\%) }\end{array}$ \\
\hline \multirow{2}{*}{ LG Household \& Health Care } & The FACE SHOP & 11.8 & 11.8 & 100 & 0 & 0 \\
\hline & BEYOND & 11.1 & 17.1 & 100 & 0 & 34.7 \\
\hline \multirow{2}{*}{ Able C\&C cosmetic } & MISSHA & 6.3 & 6.3 & 50.0 & 50.0 & 50.0 \\
\hline & A'pieu & 6.3 & 3.1 & 50.0 & 50.0 & 0 \\
\hline \multirow{2}{*}{ Amore Pacific cosmetic } & innisfree & 30.7 & 24.7 & 60.2 & 39.8 & 25.4 \\
\hline & ETUDE HOUSE & 9.4 & 6.3 & 33.3 & 66.7 & 50.0 \\
\hline Other Brand & & 24.4 & 30.7 & 87.1 & 12.9 & 30.7 \\
\hline Total & & & & & & \\
\hline
\end{tabular}


분석을 동시에 실시하여 각 평가대안 브랜드의 충성도와 이탈고객 률 그리고 다른 평가대안 브랜드로부터의 신규유입고객률을 분석 하였으며 연구결과는 다음과 같다.

첫째, Bass (1969) 확산모형의 추정결과는 평가대상 브랜드 모 두가 cannibalization이 예상되고 있으며, 혁신계수보다 모방계수 의 값이 더 높게 나타나 진입비율이 증가하게 되며 신상품이 전파 되는데 있어서 외부 영향보다는 입소문 영향이 더 중요하게 되며, Sultan et al. (1990) 연구와 같이 어떤 제품을 확산하는데 있어 모 방이 혁신보다 중요하다는 것을 의미한다고 할 수 있다. 확산과정 에서 모방계수에 의하여 확산이 주도되는 특징이 있으며(Talukdar et al., 2002), 모방계수의 값이 클수록 확산은 빠르게 일어나는 (Lee et al, 2015) 선행연구와 같이 본 연구결과에서도 동일하게 적용되는 것으로 나타났다.

둘째, positioning map 분석 결과에 의하면 아모레퍼시픽그룹 의 하향된 패밀리 브랜드 이니스프리와 에뛰드하우스는 평가요소 인 '상호연상되는 브랜드 간의 고유한 개성의 차별화', '상호연상 되는 브랜드 간 구색의 다양함의 차별화', '상호연상되는 브랜드 간 구매촉진 서비스의 차별화' 그리고 '상호연상되는 브랜드 간 점 포 이미지의 차별화' 등이 eucledian distance가 근접하게 붙어 있 는 것으로 나타났으며, 하향확장된 두 브랜드를 중심으로 차별화 되지 못한 이들 평가요소의 유사성으로 cannibalization 현상이 예 상되고 있음을 알 수 있다. 따라서 이들 몰정체성된 평가요소의 정 체성 차별화를 통하여 cannibalization을 예방할 수 있을 것이다. Sridhar Moorthy (1984)와 Sridhar Moorthy \& Png (1992)는 cannibalization 현상이 발생하는 경우 이윤의 극대화를 위해 브랜 드에 대한 고품질과 고가격을 특성으로 하는 상품차별화 전략을 수 행하여야 한다고 하였다.

그리고 $\mathrm{LG}$ 생활건강의 더페이스샵과 비욘드 브랜드의 경우는 positioning map 상에서 브랜드간의 eucledian distance가 상대적 으로 멀리 나타나 다른 평가대안 브랜드 보다 유사성이 상대적으로 낮은 것으로 도출되어져 cannibalization 현상을 무시하여도 되는 낮은 수준으로 나타났다.

셋째, 단기미래시장점유율로부터 이탈률과 신규고객유입을 살펴 보면 평가대안 브랜드 중 에뛰드하우스가 가장 높은 이탈률을 보이 고 있는 것으로 나타났으며, 신규고객유입이 이루어지고 있으나 이 들은 모두 같은 모브랜드인 아모레퍼시픽그룹의 패밀리 브랜드인 이니스프리의 고객으로부터 유입되는 고객으로서 cannibalization 현상이 발생하는 것으로 해석된다.

넷째, 저가화장품 시장에서 브랜드 포트폴리오 확장전략으 로 인한 발생가능한 cannibalization 현상의 분석을 위해 도입 한 Bass (1969) 확산모형과 positioning map 분석 그리고 교차 분석을 이용하여 분석한 결과 아모레퍼시픽그룹의 패밀리 브랜드 인 이니스프리와 에뛰드하우스의 경우 시장점유율과는 무관하게 cannibalization이 세 가지 분석에서 모두 발생하는 것으로 나타나
주의를 요하는 것으로 나타났다.

Positioning map 분석과 교차분석의 결과로부터 이니스프리의 경우 시장점유율이 가장 높게 나타났으며, 가장 낮은 시장점유율로 나타난 브랜드는 미샤와 어퓨로 이 두 가지 분석에서 유사한 점유 율을 보이고 있어 이 분석결과는 서로 밀접한 연관성이 있는 것으 로 나타났다.

본 연구는 일부 지역의 저가화장품 이용 소비자를 대상으로 표 본구성을 하여 진행하였으므로 연구 결과를 일반화하기에는 제한 점을 가질 수 있어 연구 지역과 대상을 확대 적용할 필요가 있으며, 다양한 평가요소를 도입하여 세분화하는 후속연구가 이루어지기를 기대한다.

\section{Acknowledgements}

This work was supported by the Ministry of Education of the Republic of Korea and the National Research Foundation of Korea (NRF-2017S1A5B5A07064533).

\section{Author's contribution}

MSS alone contributed to this work. The author designed all experiments, performed a pre-test, and collected analyzed and interpreted the data regarding physical and written responses. The author also wrote the manuscript and oversaw the project.

\section{Author details}

Man Seok Song (Lecturer), Department of Advertising and PR, Tongmyong University, 428, Sinseon-ro, Namgu, Busan 48520, Korea.

\section{References}

Bae SW. The effect of regulatory focus and brand awareness of parent-extension dissimilarity on brand extension evaluation. Korean Journal of Sport Management, 20: 103-115, 2015.

Bass FM. A new product growth model for consumer durables. Management Science, 15: 215-227, 1969.

Broniarczyk SM, Alba JW. The importance of the brand in brand extension. Journal of Marketing Research, 31: 214-228, 1994.

Copulsky W. Cannibalism in the marketplace. Journal of Marketing, 40: 103-105, 1976.

Fraser C, Bradford JW. Competitive market structure analysis: 
Principal partitioning of revealed substitutabilities. Journal of Consumer Research, 10: 15-30, 1983.

Jamieson LF, Bass FM. Adjusting stated intention measures to predict trial purchase of new products: a comparison of models and methods. Journal of Marketing, 26: 336345, 1989.

John DR, Loken B, Joiner C. The negative impact of extensions: can flagship products be diluted? Journal of Marking Research, 62: 19-32, 1998.

Kim TH, Shin HD. The economic impact of cannibalization strategy: a response to new technological breakthrough. Journal of Strategic Management, 11: 27-42, 2008.

Kwon HY, Kim SD. The influence of brand reputation and chronic regulatory focus on the non-similar brand extension. Journal of Digital Convergence, 11: 167-174, 2013.

Lee BS, Kim SH, Kang JA. Categorical differentiation strategy of AmorePacific's cushion foundation. Business Education Research, 31: 191-214, 2016.

Lee HN, Kim DH, Kang JS, Lee D, Kim YB. Impact comparison of WIPI policy based on the bass model: domestic smartphone case. Korean Telecommunications Policy Review, 22: 1-18, 2015.

Lee SE. Effects of visual images of low-cost cosmetics on consumer types and their behaviors. Asian Journal of Beauty and Cosmetology, 14: 30-41, 2016.

Loken B, John DR. Diluting brand beliefs: when do brand extensions have a negative impact? Journal of Marketing, 57: 71-84, 1993.

Lomax W, Hammond K, East R, Clemente M. The measurement of cannibalization. Journal of Product \& Brand Management, 6: 27-39, 1997.

Mason CH, Milne GR. An approach for identifying cannibalization within product line extensions and multibrand strategies. Journal of Business Research, 31:
163-170, 1994.

Peres R, Muller E, Mahajan V. Innovation diffusion and new product growth models: a critical review and research directions. International Journal of Research in Marketing, 27: 91-106, 2010.

Reddy SK, Holak SL, Bhat S. To extend or not to extend: success determinants of line extensions. Journal of Marketing Research, 31: 243-262, 1994.

Shin $\mathrm{CH}$. Research methods and a new multi-generation diffusion model for analyzing the cannibalization of telecommunications products. Industry and Management, 4: 1-16, 1997.

Song MS. A study on the repositioning strategy for competitiveness of enterprise in low-cost cosmetics market. Asian Journal of Beauty and Cosmetology, 16: 405-416, 2018.

Song MS, Seol SC. A study on the consumer's selection attributes priority and repositioning for the efficient market competitiveness of financial institutions. Industrial Innovation Research, 32: 83-110, 2016.

Sridhar Moorthy K. Market segmentation, self-selection, and product line design. Marketing Science, 3: 288-307, 1984.

Sridhar Moorthy K, Png IPL. Market segmentation, cannibalization and the timing of product introductions. Management Science, 38: 345-359, 1992.

Sultan F, Farley JU, Lehmann DR. A meta-analysis of applications of diffusion models. Journal of Marketing Research, 27: 70-77, 1990.

Talukdar D, Sudhir K, Ainslie A. Investigating new product diffusion across products and countries. Marketing Science, 21: 97-114, 2002.

Urban GL, Johnson PL, Hauser JR. Testing competitive market structures. Marketing Science, 3: 83-112, 1984. 


\section{국문초록}

\section{저가화장품 시장에서의 브랜드 확장 포트폴리오 전략이 Cannibalization에 미치는 영 향에 관한 연구}

송만석

동명대학교 광고홍보학과, 부산, 한국

목적: 본 연구는 저가화장품시장에서 브랜드 포트폴리오 확장전략으로 하향확장된 패밀리 브랜드 간의 cannibalization 분석으 로 LG생활건강의 더페이스샵과 비욘드, 에이블씨엔씨의 미샤와 어퓨, 그리고 아모레퍼시픽의 이니스프리와 에뛰드하우스를 평가 대안으로 선정하여 Bass 확산모형을 적용하여 cannibalization을 분석하였으며, 다른 복수의 분석방법으로 교차분석을 실시하여 cannibalization 분석과 다른 브랜드로의 전환의도를 파악하고, positioning 분석을 동시에 실시하여 cannibalization 분석과 경쟁 브 랜드와의 시장잠식 그리고 시장경쟁력 측정을 위한 연구를 수행하였다. 방법: 본 연구를 수행하기 위한 자료 수집은 2018년 3월 20 일부터 4월 21 일까지 진행되었다. 저가화장품을 사용한 경험이 있는 성인여성을 대상으로 편의 표집 조사하였으며, 배포한 총 300 부 중 13 부의 부적합한 설문지를 제외하고 287 부를 회수하여 최종 자료로 사용하였다. 수집된 자료는 SPSS사의 통계패키지 프로 그램을 이용하여 평가대상 저가화장품 브랜드 구매실태 및 향후 브랜드 전환확율을 파악하기 위하여 교차분석을 실시하였으며, biplot 분석을 실시하여 positioning map을 작성하였으며, 인구통계적 분석을 위해서 빈도 분석도 실시하였다. 그리고 각 평가대안 브 랜드의 매출 시계열 자료를 이용하여 Bass 확산모형 분석을 실시하였다. 결과: Bass 확산모형의 추정결과는 평가대상 브랜드 모두 가 cannibalization이 예상되어지고 있으며, 혁신계수보다 모방계수의 값이 더 높게 나타나 진입비율이 증가하게 되며 신상품이 전 파되는데 있어서 외부 영향보다는 입소문 영향이 더 중요하게 된다. 그리고 시장조사분석 결과에서 더페이스샵의 경우 가장 높은 충성도를 보여주고 있으며, 에뛰드하우스의 경우 가장 높은 이탈고객율( $65.4 \%)$ 을 가지고 있으면서 가장 높은 신규고객율(50.0\%)도 가지고 있는 것으로 나타났다. 이 유입고객은 모두 같은 패밀리 브랜드(아모레퍼시픽 화장품)인 이니스프리로부터 유입되는 것으로 나타나 cannibalization이 이루어지고 있으며, positioning map 분석 결과에 의하면 에뛰드하우스와 이니스프리의 cannibalization 이 역시 예상되어지고 있으며 미샤와 어퓨 역시 cannibalization이 예상되어지는 결과를 나타내고 있다. 결론: 저가화장품 시장에서 의 cannibalization 분석을 위한 연구는 격심한 경쟁구조에서 확장된 브랜드 포트폴리오의 성과 측정, 신제품 출시뿐만 아니라 브랜 드의 신규시장 진출, 경쟁브랜드와의 시장경쟁구조분석 그리고 cannibalization 방어전략의 제시 등 다양한 분야에 적용 가능한 시 사점을 제시할 수 있다.

핵심어: 저가화장품, 브랜드 확장, 자기시장잠식, Bass 확산모형, 지각도

이 논문은 2017년 대한민국 교육부와 한국연구재단의 지원을 받아 수행된 연구임 (NRF-2017S1A5B5A07064533).

\section{참고문헌}

김태하, 신형덕. 신기술 개발에 대처하기 위한 자기시장 잠식의 의사결정. 전략경영연구, $11: 27-42,2008$.

권혁윤, 김상대. 브랜드명성과 성향조절초점이 비유사 브랜드확장에 미치는 영향. 디지털융복합연구, 11: 167-174,

2013.

배성우. 스포츠 브랜드의 비유사 브랜드확장 시 조절초점과 브랜드인지도가 확장제품평가 및 구매의도에 미치는 효과. 한 국스포츠산업경영학회지, 20: 103-115, 2015.

송만석. 저가화장품 시장에서의 기업 경쟁력 강화를 위한 리포지셔닝 전략에 관한 연구. 아시안뷰티화장품학술지, 16 : 405-416, 2018. 
송만석, 설상철. 금융기관의 효율적인 시장 경쟁력 강화를 위한 소비자의 선택속성 우선순위와 리포지셔닝에 관한 연구. 산업혁신연구, 32: 83-110, 2016.

신창훈. 통신상품 자기시장잠식 분석을 위한 방법론 고찰 및 확산모형. 산업과 경영, 4: 1-16, 1997.

이방실, 김상훈, 강진아. 아모레퍼시픽'쿠션(cushion)'화장품의 범주적 차별화(categorical differentiation) 전략. 경영교 육연구, 31: 191-214, 2016.

이상은. 저가화장품 시각적 이미지가 소비자유형과 구매행동에 미치는 영향. 아시안뷰티화장품학술지, 14: 30-41, 2016. 이하늘, 김대희, 강지석, 이동환, 김윤배. Bass 모형을 통한 WIPI정책의 영향 분석: 스마트 폰 시장을 중심으로. 정보통신 정책연구, 22: 1-18, 2015. 


\section{中文摘要}

\section{低价化妆品市场的品牌扩张组合战略对自我市场蚛食产生的影响}

宋晚碩

东明大学广告宣传系，釜山，韩国

目的: 本研究旨在通过分析低价化妆品市场上通过品牌组合扩张战略向下扩张的家庭品牌的自有市场峑食, 适用 Bass扩散模型, 分析自有市场蚕食, 并通过其他复数的分析方法进行交叉分析, 确认品牌购买意图和转换意图, 自 有市场蚕食分析和竞争品牌的市场蚕食, 以及为测定市场竞争力而执行研究。方法: 为执行本研究, 从2018年3月 20 日到4月21日进行了资料收集。以有使用低价化妆品经验的成人女性为对象进行了便利抽样, 分发的共300份 中, 除了13份不合格的调查问卷以外, 回收了287份, 用作最终资料。对收集的资料利用SPSS社的统计包程序进 行了交叉分析和频度分析, 制作了知觉图。此外, 利用各评价代案品牌的销售额时系列资料进行了Bass扩散模型 分析。结果: 根据Bass扩散模型的推测结果, 所有的评价对象品牌都预测存在自有市场蚕食, 本研究结果中, The FACE SHOP的情况, 呈现最高的忠诚度, ETUDE HOUSE的情况, 呈现最高脱离客户率(65.4\%)的同时呈现最高的 新客户率 $(50.0 \%)$, 自有市场虫食正在进行, 根据知觉图分析结果, 预测ETUDE HOUSE和innisfree也存在自有市 场䖯食。结论: 关于低价化妆品市场上的自有市场菳食分析的研究不仅为激烈竞争构造中扩张的品牌组合的成果 测定、新产品上市, 而且还为品牌的新市场进军, 与竞争品牌的市场竞争构造分析以及自有市场菳食防御战略的 提出等各种领域提出可适用的启示。

关键词: 低价化妆品，品牌扩张，自有市场蚕食，Bass扩散模型，知觉图 
